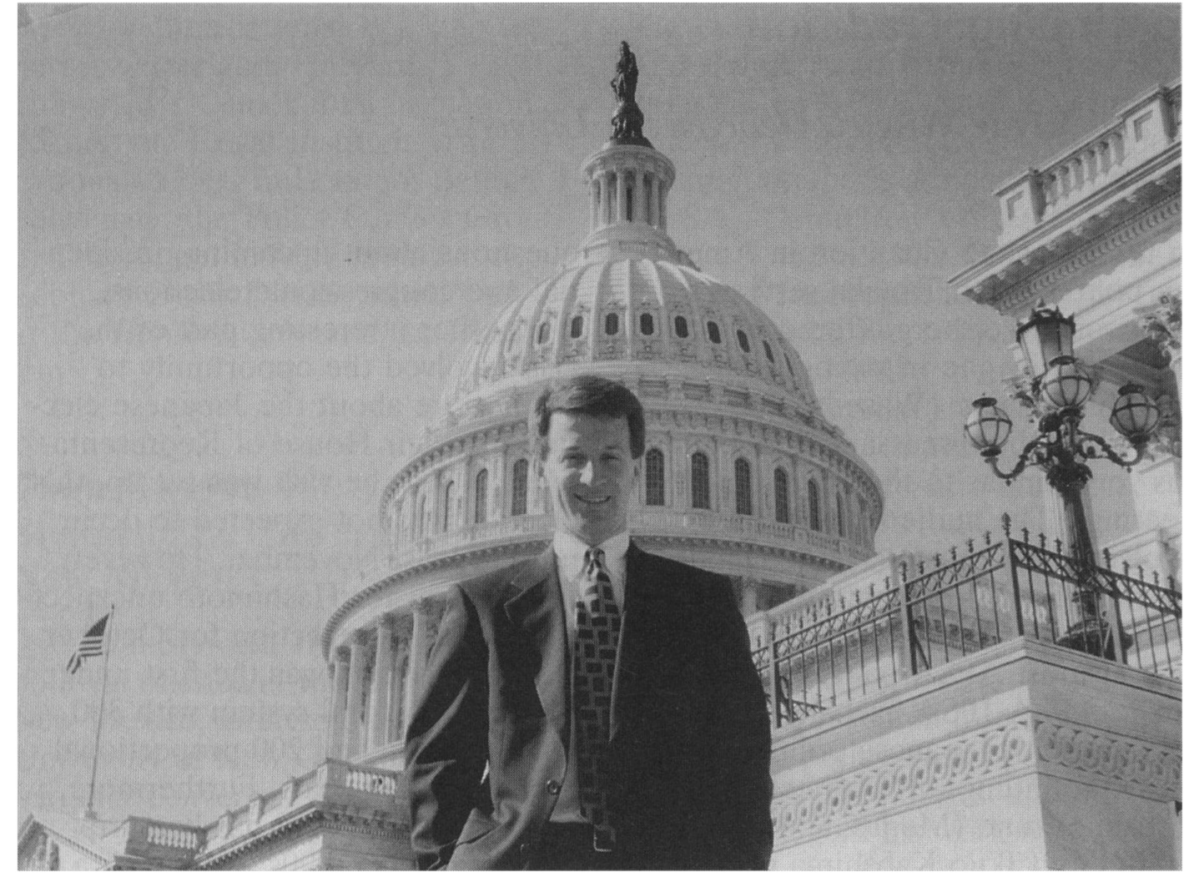

Patrick Sellers

\section{Working for the Minority}

For political scientist Patrick Sellers, whose scholarship has focused on congressional campaigns, changing his professional focus to working in a Senate office came naturally. A self-proclaimed "political hack" and a 1996-97 APSA Congressional Fellow, Sellers has settled into his office in the Capitol building working for Senate Minority Leader Tom Daschle (D-SD). His responsibilities at Indiana University in Bloomington have been temporarily traded in to work on campaign finance reform, judiciary matters, and his main charge of helping the Senate Minority frame its budget message and pitch it to the media, a process he describes as a sometimes "awkward ballet" among his office, the Senate Majority, and the president.

Sellers is a $1994 \mathrm{Ph} . \mathrm{D}$. from Duke University whose major research focus has been on how congressional candidates enhance their credibility among the media and voters by emphasizing issues on which they have built a favorable record of accomplishment. By examining campaign themes of various candidates and comparing them with the backgrounds of the candidates, Sellers has shown why some campaign messages are successful and others fail.
"I applied for a Congressional Fellowship because I wanted to look at the different aspects of American government, and the legislative arena is very different from the electoral arena," Sellers reported But as he began to focus on the legislative side of politics, Sellers was surprised by similarities with the electoral side. "As in campaigning, developing a message is a very important part of the legislative process," Sellers said. "What has impressed me most is how heavily the congressional leadership relies on message development. My background studying message development in campaigns has helped the leadership think about it in the legislative context."

Sellers sees his experience in the Congressional Fellowship Program as an opportunity to expand his research, though, he remains in the "soaking and poking" stage. "I can see my research expanding from work on elections to work on the legislative process. Right now I'm trying to follow the rationale behind the decisions that are made and comparing what happens in strategy meetings to what happens in the media, she said."

This is not Sellers' first stint on Capitol Hill. After graduating from Davidson College in North Carolina, Sellers spent nearly two years working in the office of Representative James McClure Clarke (D-NC) who left the House in 1991. Sellers says his experience in Clarke's office helped frame his work as a political scientist.

"Clarke was in what was the most competitive district in the country during the 1980s. From 1982 until 1990, no candidate won election in that district by more than $1 \%$, so working for Clarke gave me my first good taste of elections, and then I went on to study them."

Though he has enjoyed his time on the Hill, Sellers has no interest in making a run for electoral office. When he returns to Indiana in the fall, Sellers will keep in contact with Capitol Hill by acting as an academic advisor to Indiana undergraduates who serve as interns in Washington.

\section{German Marshall Fund Expands Grant to Congressional Fellows}

The German Marshall Fund of the United States has for 15 years provided funding for German academics to serve as APSA Congressional Fellows. Until now, German Fellows were not consistently funded to participate for the full ten-months of the fellowship program. But in February, the German Marshall Fund agreed to extend the grant for German Fellows to spend the full fellowship year on Capitol Hill, beginning with this year's Fellows.

During the 1996-97 fellowship year, Kirsten Gerstner and Thomas Zittel are the German academics participating as APSA Congressional Fellows. Gerstner recently received her master's degree in political science from the Free University of Berlin and works on human rights issues in the office of Representative Jim McDermott (D-WA). Zittel teaches political science at the University of Mannheim and took his masters degree from Johns Hopkins University in 1990 and his doctoral degree at the University of Mannheim in 1995. He has served his fellowship in the office of Representative Michael Oxley (R-OH) focusing on the issues of environment and technology.

In addition to funding APSA Con- 


\section{Washington Insider}

- In 1998, the National Science Foundation will conduct a competition to fund new Science and Technology Centers (STCs). Since 1987, the NSF has established 25 research centers, including one in psychology, presently the only STC focusing on a social science. The competition will be open to all sciences and will potentially establish eight centers for scientific research from a pool of $\$ 25$ million. Centers can be funded for a maximum of 10 years. For application information, contact Dr. Fernanda Ferreira of NSF's Social, Behavioral, and Economic Sciences Directorate. Dr. Ferreira can be reached at (701) 306-1731 or $<$ fferreir@nsf.gov>.

- The National Science Foundation is revising its process for reviewing grant proposals. NSF will ask reviewers to consider these two broad questions in evaluating grant proposals: 1) What is the intellectual merit and quality of the proposed activity, and 2) What are the broader impacts of the proposed activity? Under the two broad questions and a longer list sub-questions, reviewers will focus more of their evaluation on how proposals seek to serve society. Pending final approval, these new guidelines could be implemented as early as the fall of 1997 .

- "Valuable resources are wasted every time an important policy decision is made without regard to the science and technology research that could be tapped to inform that decision." So state the heads of the National Academies of Science and Engineering and the Institute of Medicine. These organizations have jointly published Preparing for the 21st Century, a series of six papers on the relationship between social science research and public policy. These papers be accessed on the web at $<$ http// www2.nas.edu/21st>.

- The United States Information Agency (USIA) announced that the Institute for International Education (IIE), headquartered in New York City, has assumed administrative responsibility for the Fulbright Senior Scholars Program, formerly administered by the American Council of Learned Societies. Each year, the Fulbright Senior Scholars Program sends approximately 800 American academics to more than 125 countries.

- President Clinton has called for a $3.4 \%$ increase in National Science foundation funding for the fiscal year 1998, raising NSF's budget to $\$ 2.5$ billion. Under Clinton's proposal, the budget for the Social, Behavioral, and Economic Sciences Directorate of NSF would increase to $\$ 129.7$ million, up 6.5\% from FY 1997. Representative Vern Ehlers (R-MI), vice-chair of the House Science Committee and head of the Committee's two-year study of science and technology policy, commented that the President's NSF budget represents "a realistic proposal from which we on the science committee can work." Support for the Clinton proposal is also evident in Representative James Sensenbrenner (R-WI), chair of the Science Committee. gressional Fellows from Germany, the German Marshal Fund, in conjunction with the Franco-American Commission for Educational Exchange, supports Congressional Fellows from France.

\section{APSA Congressional Fellow Rises in Army's Ranks}

APSA Congressional Fellow Michael Gayle has been promoted to the rank of lieutenant colonel in the United States Army. Gayle's promotion ceremony took place in February in the office of Representative J.C. Watts (R-OK) where he is currently serving as a Congressional Fellow. Major General Peter Franklin, USA, officiated at the ceremony, and Pam Pryor, deputy staff director for Congressman Watts, offered congratulations on behalf of the congressman.

A 1980 graduate of the United States Military Academy at West Point, Gayle has spent over 15 years in management positions in the army. In order to participate in the Congressional Fellowship Program, Gayle is on leave from his position in the office of the Assistant Secretary of the Army for Research, Development, and Acquisition where he works on the aviation acquisitions staff.

Gayle is one of three army officers who are 1996-97 APSA Congressional Fellows.

\section{APSA Hosts East Europeans through International Civics Project}

In an effort to extend civics education projects in former communist bloc countries, APSA is hosting delegations of scholars and teachers at its national headquarters. Funded by the US Department of Education and coordinated by the Center for Civics Education, the American Federation of Teachers and several American colleges and universities are conducting study tours for groups of political scientists from Russia, Latvia, Poland, Bosnia, Hungary, and the Czech Republic. The program seeks to enable a mutual exchange of ideas about civics edu- 